\title{
V Międzynarodowa Konferencja Naukowa
}

„Pogranicza: kontakty kulturowe, literackie, językowe"

Białystok, 14-15 listopada 2019 r.

W dniach 14-15 listopada 2019 r. na Wydziale Filologicznym UwB odbyła się V Międzynarodowa Konferencja Naukowa pt. „Pogranicza: kontakty kulturowe, literackie, językowe". Organizatorem sesji była Katedra Językoznawstwa Slawistycznego, Zakład Językoznawstwa Wschodniosłowiańskiego i Onomastyki Regionalnej. 
Zakres tematyczny konferencji obejmował zagadnienia dotyczące specyfiki pogranicza w kontekście multikulturowości, wyrażanej na poziomie języka, literatury oraz kultury. Zaproponowana problematyka spotkała się z zainteresowaniem badaczy z różnych ośrodków naukowych Polski, Białorusi, Gruzji, Rosji i Ukrainy.

Prof. dr hab. Leonarda Dacewicz, kierownik Katedry Językoznawstwa Slawistycznego, otworzyła konferencję w imieniu organizatorów, a następnie poprowadziła pierwszą część obrad. Byli wysłuchany referaty: dr Olgi Polietajewej (Miński Państwowy Uniwersytet Lingwistyczny) - „Семантическая деривация глаголов в свете теории лингвистической непрерывности”, dr hab. Elżbiety Bogdanowicz (Uniwersytet w Białymstoku) - „Podlaskie nazwiska jako nośnik regionalnego dziedzictwa kulturowego", prof. Manana Mikadze i Andro Leladze (Państwowy Uniwersytet w Kutaisi im. Akaki Cereteli) - „Литературные аллюзии и языковые параллели у Николоза Бараташвили и Адама Мицкевича (стихотворение «Мерани» и поэма «Фарис»)", ks. dr hab. Zbigniewa Stępniaka (Uniwersytet Warmińsko-Mazurski w Olsztynie) - „Wileńskie inspiracje poetyckie w pieśniach Stanisława Moniuszki".

Moderatorem drugiej części obrad była dr hab. prof. UwB Halina Twaranowicz. Swoje referaty wygłosili: doc. dr Ludmiła Czernyszowa (Miński Państwowy Uniwersytet Lingwistyczny) - „Языковая репрезентация базовой эмоции гнев в русском и белорусском языках", prof. Cira Dżandżhawa (Instytut językoznawstwa im. A. Czikobawa, Tbilisi) - „О языковых контактах в Грузии", ks. dr Adam Bielinowicz (Uniwersytet Warmińsko-Mazurski w Olsztynie) - „Współpraca Akademii Trzeciego Wieku w Olsztynie z polskimi Uniwersytetami Trzeciego Wieku na Białorusi, Litwie, Łotwie, Rosji i Ukrainie na rzecz zachowania tożsamości kulturowej”, dr Joanna Wasiluk (Uniwersytet Warszawski) - „Англоязычные заимствования в русских рекламных текстах (на примере глянцевых журналов «Караван историй» и «Домашний очаг»)", dr hab., prof. UwB Halina Twaranowicz (Uniwersytet w Białymstoku) - „Духоўныя каштоўнасці ў паэтычнай творчасці Зніча (Алега Бембеля)", prof. dr hab. Leonarda Dacewicz (Uniwersytet w Białymstoku) - „Zasób imion chrzestnych i motywacje ich nadawania w wybranych parafiach dekanatu białostockiego w II poł. XIX wieku".

W części trzeciej - prowadzonej przez dr hab. Elżbietę Bogdanowicz - głos zabrali m.in.: doc. dr Zoja Sidorewicz (Grodzieński Uniwersytet Państwowy im. J. Kupały) - „Современная женская проза как литературное явление”, dr Anna Alsztyniuk (Uniwersytet w Białymstoku) - „Антиутопические произведения Евгения Замятина и Василя Гигевича", doc dr Mirosława Szewczenko (Київський національний університет імені Тараса Шевченка) i dr Olga Anchimiuk (Uniwersytet w Białymstoku) - „Гумористичний текст як засіб формування культурологічної та орфоепічної компетенцій”, dr Michał Mordań (Uniwersytet w Białymstoku) „Nazwiska z formantem -yk/-czyk na Białostocczyźnie. Uwagi interpretacyjne”, доц. к.ф.н. Галина Гиржева (Новгородский государственный университет имени Ярослава Мудрого), „Современная русская акцентология”, dr Anna Romanik (Uniwersytet w Białymstoku) - „O wyzwaniach i problemach współczesnego językoznawstwa normatywnego (na przykładzie zapożyczeń)”, dr Jolanta Chomko (Uniwersytet w Białymstoku), „Koloratywy w «Biegnaccej po falach» Aleksandra Grina (paleta barw achromatycznych)". 
Obrady, co należy z uznaniem podkreślić, zostały perfekcyjnie zorganizowane. Organizatorzy przewidzieli pracę w jednej sekcji, dzięki czemu uczestnicy konferencji mieli możliwość wysłuchania wszystkich prelegentów. Wygłoszone referaty stanowiły inspirację dla ożywionych formalnych i kuluarowych dyskusji.

Po zamknięciu obrad i podsumowaniu konferencji jej uczestnicy wysłuchali koncertu „Stanisław Moniuszko - kompozytor Pogranicza - w 200-lecie Urodzin”. Dzień obrad zamknęła uroczysta kolacja, w czasie której wyrażono wdzięczność organizatorom oraz nadzieję na dalszą współpracę.

Drugiego dnia konferencji jej uczestnicy wyruszyli wraz z przewodnikiem na spacer po centrum Białegostoku. Pierwszym punktem programu było zwiedzanie barokowego Pałacu Branickich i jego ogrodów, a także Muzeum Historii Medycyny i Farmacji Uniwersytetu Medycznego w Białymstoku. Kolejnym punktem programu było zwiedzanie zabytkowych okolic XVIII-wiecznego Ratusza Miejskiego, Bazyliki archikatedralnej Wniebowzięcia Najświętszej Maryi Panny, a także Bazyliki św. Rocha. W trakcie wycieczki uczestnicy konferencji podkreślali wysoki poziom merytoryczny referatów oraz miłą atmosferę panującą podczas całego pobytu w Białymstoku.

Anna Alsztyniuk

Uniwersytet $w$ Bialymstoku

https://orcid.org/0000-0002-6013-2430 